\title{
THE IMPORTANCE OF STUDYING HUMAN BRAIN
}

Maja Jakovcevski ${ }^{1}$, Slobodanka Mitrović2 ${ }^{2}$ Igor Jakovcevski ${ }^{3}$

${ }^{I}$ Department of Anatomy, Faculty of Medical Sciences, University of Kragujevac, Kragujevac, Serbia

${ }^{2}$ Department of Pathology, Faculty of Medical Sciences, University of Kragujevac, Kragujevac, Serbia

${ }^{3}$ Institute for Neuroanatomy and Molecular Brain Research, Ruhr University Bochum, Bochum, Germany

\author{
ZNACAJ ISTRAŽIVANJA LJUDSKOG MOZGA \\ Maja Jakovcevski ${ }^{1}$, Slobodanka Mitrović ${ }^{2}$, Igor Jakovcevski ${ }^{3}$ \\ ${ }^{l}$ Katedra za anatomiju, Fakultet medicinskih nauka, Univerzitet u Kragujevcu, Srbija \\ ${ }^{2}$ Katedra za patologiju, Fakultet medicinskih nauka, Univerzitet u Kragujevcu, Srbija \\ ${ }^{3}$ Odsek za Neuroanatomiju i Molekularno istraživanje mozga, Ruhr University Bochum, Bohum, Nemačka
}

\begin{abstract}
Due to its numerous distinctive functions and unique pathology, the human brain, or rather forebrain has been difficult to study in common animal models. Although many basic molecular and cellular events are conserved across species, human brain connectivity, pertinent especially to the cerebral cortex circuitry, is unique and demands extensive research. Despite a great advancement in functional imaging methods accomplished over the last two decades, many basic features of healthy and diseased human forebrain remain elusive. Here we address difficulties in anatomical studies of developing and adult human brain and indicate the new directions and challenges to be addressed in the future. We pay special attention to possibilities of translating animal brain research to human cases. We consider that, although animal experiments play a vital role in understanding fundamental molecular and cellular mechanisms behind brain function, understanding of higher brain functions (language, intelligence, memory) has to be based on understanding uniqueness of human circuitries. Furthermore, brain is the site of many human-specific diseases, such as multiple sclerosis, schizophrenia, and Alzheimer's disease, for which only partial animal models exist. To study human brain, thus, remains irreplaceable in the quest for new therapeutic tools, as well as in understanding the essence of our being.
\end{abstract}

Keywords: cerebral cortex, development, hippocampus, human, patient HM.

\section{SAŽETAK}

Ljudski prednji mozak usled svojih brojnih karakterističnih funkcija i jedinstvene patologije teško je proučavati na uobičajenim životinjskim modelima. Iako su mnogi osnovni molekularni $i$ ćelijski procesi prisutni u svim vrstama, veze ljudskog mozga, posebno kortikalne, jedinstvene su i zahtevaju opsežna istraživanja. Uprkos velikom napredku u funkcionalnim metodama snimanja (fNMR) ostvarenom u poslednje dve decenije, mnoge osnovne karakteristike zdravog i obolelog ljudskog prednjeg mozga ostale su nepoznate. Ovde se bavimo poteskoćama u anatomskim studijama ljudskog mozga, kako intrauterino tako i kod odraslih osoba i ukazujemo na nove pravce i izazove sa kojima će se budući istraživači susretati. Posebnu pažnju smo posvetili mogućnosti ekstrapolacije rezultata istraživanja sa životinjskih modela na ljuski mozak. Smatramo da, iako eksperimenti na životinjama igraju vitalnu ulogu u razumevanju osnovnih molekularnih i ćelijskih mehanizama koji stoje iza funkcije mozga, razumevanje viših moždanih funkcija (jezika, inteligencije, pamćenja) mora biti zasnovano na razumevanju jedinstvenosti ljudskih moždanih sinaptičkih kola. Štaviše, mozakje mesto nastanka mnogih bolesti specifičnih za ljude, poput multiple skleroze, šizofrenije i Alchajmerove bolesti, za koje postoje samo delimični životinjski modeli. Dakle, proučavanje ljudskog mozga ostaje ostaje nezamenjivo u potrazi zaa novim terapijskim pristupima, kao i u razumevanju suštine našeg bića.

Ključne reči: moždana kora, razvoj, hipokampus, људски мозак, pacijent HM. 


\section{INTRODUCTION}

It is in the nature of consciousness to try to uncover the origin of itself. Over the millennia human thought has evolved in giving an answer to this fundamental question through mystic, religion, art, philosophy and, particularly during the last few centuries, science. Neuroscience provides a unique perspective by placing consciousness inside of the brain (1).

Human brain is a unique structure in the known universe able to study itself. As the source of material for morphological studies of the human brain is sparse, numerous animal models have been used. Most notably, rodent species, mouse (Mus musculus) and rat (Rattus rattus) have been widely used in many other areas of research, as well as in neurosciences. Whereas the advantages of this reductionist approach are clear, these animals have relatively short gestation, numerous offspring, small size, simple diet, just to name a few advantages, there is an important caution when they are used for neuroscience research. Although all other organs and tissues in rodents are miniature versions of their human counterparts, it is not the case with the brain.

Based on this variation, neuroscientists have come up with a measure called the encephalization quotient (EQ) which describes brains size as a ratio of the expected average brains size for a given body weight (2). For example, humans have an EQ of about 7.5. This means that our brains are 7.5 times bigger than what one would expect for animals of our body size. In contrast, a squirrel has an EQ of 1.1, meaning that their brains are quite average for animals of their size. While this is somewhat controversial, some have argued that EQ correlates with the intelligence of a species. However, this is hard to determine because there is no good measure of intelligence in animals. Nevertheless, having a larger EQ does roughly correspond to having a more "developed" brain. For example, carnivores tend to have larger EQs than plant eaters, which is consistent with the fact that hunting is a more complex task than rummaging (3).

The most vigorously studied, rodent brains are lyssencephalic, a state which is incompatible with life in humans (4). Human brain, thus, undergoes much longer development during which it increases in size, develops gyri, and, functionally, has far greater capacity for information processing, memory, thinking, and, as a pinnacle - develops consciousness. It is beyond our scope to discuss the matter of uniqueness of processes such as the perception of time, feelings, self-consciousness and all other attributes of the human soul to our species, as the evidence to the contrary is sparse we will simply accepted this as an axiom for all further considerations. The question of extraterrestrial and other-dimensional conscious life forms will also not be considered, due to lack of data.

Other animal models, particularly studies of comparative neuroanatomy of mammals have been performed ever since Cajal grounded neuroscience (5). Especially important studies comparing mammalian brain with a perspective of human brain as the result of evolution have been published by Javier DeFelipe $(6,7)$. Especially important in this context is study of non-human primate brains, as our closest evolutionary relatives $(8,9,10,11)$. Many ethical limitation, however, make this work in many ways even more difficult than work on human tissue, whereas the advantage is better and more even quality of tissue samples which are in primates obtained without post-mortem delay, as is always the case in humans.

Using several examples from the literature, we will try to build the case that, although experiments on animals are essential for the advancement of neurosciences, particularly in understanding molecular mechanisms behind physiological and pathological brain processes, parallel research on the human brain tissue samples is important as well.

\section{METHODOLOGICAL REMARKS}

Sparsely available human brain tissue for research purposes makes the possibilities for statistical analysis limited. Another problem is with the antibodies used to stain human brain tissue. Some of the usual ways of examining the specificity of antibodies in laboratory animals can simply not be applied to humans, particularly the "gold standard" method of showing the lack of immunostaining in knockout mice (12). As some antibodies do not cross-react across species, as the ultimate control for the specificity of staining - labeling of a knockout mouse tissue cannot be performed, reliability of available antibodies is difficult to prove. Other ways of controlling antibody specificity, all doable on human tissue, include the replacement of the primary antibody with the normal serum of animal in which the antibody was raised, and the immunoblot of the brain region. Another possibility is to confirm the expression with the in situ hybridization for mRNA of the protein to be probed and either double-label with the antibody or compare adjacent sections for the mRNA and protein expression. These controls are particularly important when working with the new antibody to describe the distribution of a previously unknown protein in human brain tissue (13). In general, a very important criterion is that all immunostained cells and structures have the appearance expected for the given antibody staining pattern $(14,15)$.

Larger developmental window, where many processes that in commonly used experimental animals take place within hours, or days, in human brain may take several weeks or even months (examples given below). Thus, studying human brain development, together with brains of non-human primates (where the availability of the tissue is almost equally complicated as in humans), may not only give insight into primate-specific developmental events, but also the previously unrecognized events ("missing links") in brain development shared by all mammals. Good example for the latter is that soon after the discovery of dorsally generated interneurons in humans (16), several publications reported similar developmental events in rodents $(17,18)$. 


\section{DEVELOPING HUMAN BRAIN}

According to the disputed recapitulation theory embryonic development recapitulates evolution (19). Although the theory has long been abandoned, it is a matter of fact that human brain development has many common processes with development of a rodent brain, particularly in its early stages. This has led to the dominant, simplistic view, that the difference between human and rodent brain is mainly quantitative, i.e. the longer developmental window and larger size of human brain (Fig. 1) account for most differences in the ontogeny $(20,21)$.

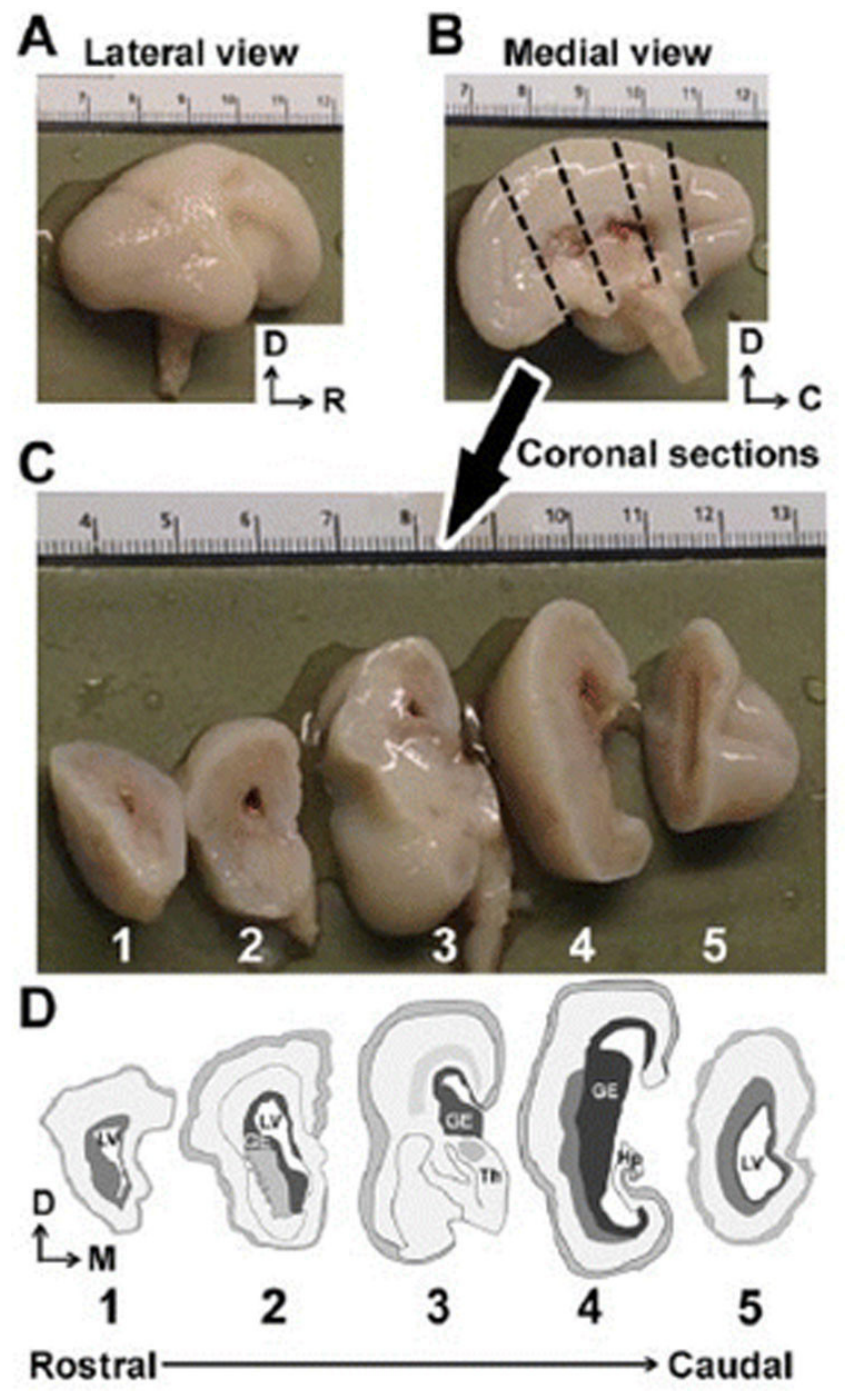

Figure 1. The human fetal brain at mid-gestation. (A) Lateral and (B) medial views of a human fetal right hemisphere at 18 gestational weeks (gw). (C, D) Images and composite drawings of a coronally sectioned right hemisphere, from the rostral (frontal) to the caudal (occipital) pole. $\mathrm{D}=$ dorsal; $\mathrm{M}=$ medial; $\mathrm{C}=$ caudal; $\mathrm{R}=$ rostral. Adopted from Ortega et al. (2017), with permission.
Dispute to this time remains unresolved, although many human-specific developmental events have been described. For example, the work in the laboratories of Pasko Rakic and Nada Zecevic in Connecticut has, not long after the discovery of tangential migration of gamma amino butyric acid (GABA)-ergic interneurons from ganglionic eminences to the cortex in rodents (22), shown that in humans the migratory paths of interneurons are more complex $(16,23)$. In humans, based on the transcription factor expression, at least two lineages of human cortical GABAergic neurons exist. One that expresses DLX1/2 and MASH1, makes up to $65 \%$ of the GABAergic interneurons. These cells originate in the ventricular and subventricular zones of the dorsal telencephalon and migrate radially to the cerebral cortex. The other lineage expresses DLX1/2 but not MASH1, and originate in the ganglionic eminence of the ventral telencephalon from where they migrate tangentially across the intermediate zone to the cerebral cortex, similar to what has been reported in rodents (22, 24). Additionally, Rakic and Zecevic (2003) have shown widespread expression of the "ventral" transcription factor NKX2.1 in dorsal cortical regions of human embryo at midgestation (around $20^{\text {th }}$ gestational week). This finding was later corroborated and extended to very early embryonal stages (beginning with 5.5 gestational weeks) (25, $26,11)$. It was, however, disputed by several groups since ( $27,28,29)$, although the evidence is mounting on both sides $(30,31)$. Time will resolve this dispute, but for the resolution further research on the developing human brain is essential $(15,31)$. It is fascinating, however, that sometimes very similar results are interpreted by various researchers in quite opposite ways.

\section{ADULT HUMAN BRAIN}

Good example for this can be found in two recently published studies in highly respected journals, both from respected scientists. Let us first consider the background: in the sixties Joseph Altman published that new neurons are generated in the adult rat dentate gyrus, which is now known to be crucial for memory (32). This finding was neglected mainly due to skepticism about the brain's capacity for plasticity. In the nineties, with the development of improved techniques for visualizing brain cells, that acceptance of adult neurogenesis became widespread (for a comprehensive review see Gross, 2000), (33). Then, the group of Alvarez-Buylla shook the scientific community by publishing the results of the analysis of many post-mortem human brain samples and discovering that the level of neurogenesis sharply drops already at young age, and is negligible in adults (34). Only a few weeks later, another paper explored the same topics, using the same method - analysis of the post-mortem human brains (35). Most strikingly, both publications describe roughly comparable numbers of newborn neurons in the adult human dentate gyrus, it is only the difference in interpretation. While one group calls the numbers of newborn neurons "negligible" the other considers them "significant". Without going into details of slight differences between the two publications, the main message is that, even with roughly comparable studies, the interpretation of results can be critically important. The 
controversy sprouted a wide debate in the scientific community, which by itself was an important and significant achievement (see e.g. Kempermann et al., 2018), (36).

It is noteworthy that examining human brains led to discoveries of important human-specific brain features. For example, a new GABAergic interneuron cell type has recently been discovered in the human neocortex (37). This is congruent with previous work showing great morphological diversity of calretinin-expressing human cortical neurons (38), mirroring thus the more complex development of these neurons $(39,40,26)$. Figure 2 illustrates some classical histochemical stainings of the adult human hippocampal formation. It is maybe more fascinating that, even by studying the most evolutionary preserved cortical structures, the archicortex, complexity of neuronal cell types and synapses in the subiculum, for example, exceeds by far what is seen in rodent brains $(41,42)$. It is, therefore, reasonable to assume that even greater complexity is present in primate-specific and human specific neocortical structures.

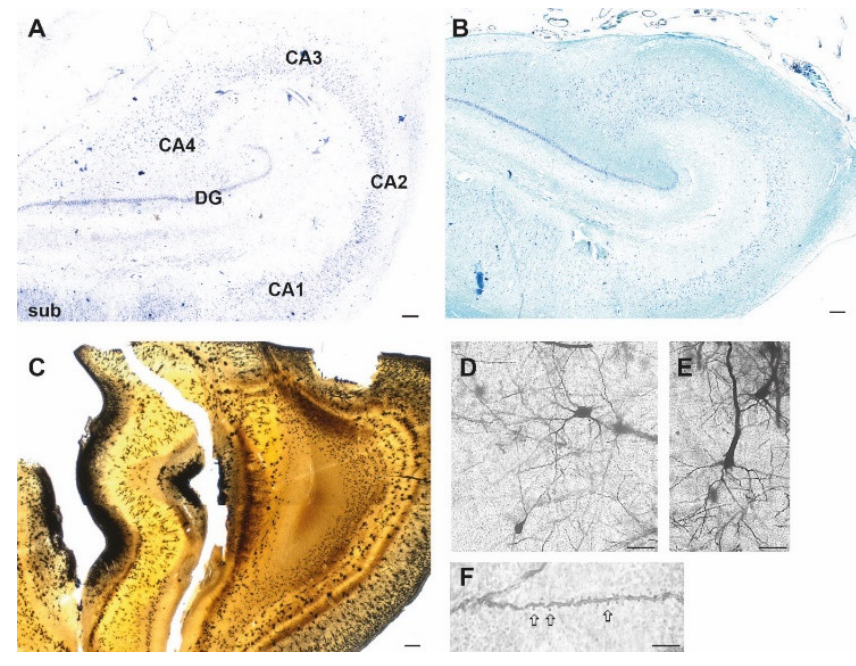

Figure 2. The human hippocampal formation. (A) Nissl staining. Seen are the subiculum (sub), CA1-4 subfields and dentate gyrus (DG). (B) Same area co-stained with Nissl (labels cell nuclei) and Luxol fast blue (staining for myelin). (C) Golgi-Cox staining, random-labeling approximately $1 \%$ of all neurons. (D) An interneuron in the CA2 region of the hippocampus stained by Golgi-Cox impregnation. (E) A pyramidal neuron in the CA2 region of the hippocampus. (F) Single dendrite of the pyramidal cell in (E). Arrows point at dendritic spines. Scale bars: $300 \mu \mathrm{m}$ (A-C); $20 \mu \mathrm{m}$ (D-E); $5 \mu \mathrm{m}$ (F).

\section{DISEASED HUMAN BRAIN}

It is not only that normal structure of the human brain is a fascinating topic for research, but the diseased brain is even more exciting. It has been self-evident that complex psychiatric disorders such as depression, schizophrenia, autism are human-specific and, although attempts of animal models exist, they are limited to model only certain aspects of disease $(43,44,45)$. Furthermore, many neurological disorders, such as multiple sclerosis, Huntington's, Parkinson's and Alzheimer's disease, have not been reported to occur spontaneously in the animal kingdom, and even their animal models fail to reproduce the main symptoms and progression of disease $(46,47,48,49)$. It is thus conceivable that gaining insights into neuropathology of these diseases in brain tissue sections is fundamental for understanding their pathogenesis and designing therapies. For example, demyelinated plaques in multiple sclerosis can be studied in tissue samples from patients (50). Finally, pathological examination of human brain sections was instrumental in discovering the main pathological features of Alzheimer's and Parkinson's diseases, leading to description of diagnostic criteria for these diseases $(51,52)$. It is a firm belief of the authors that ex vivo studies of human brain tissue samples of patients with neurological and psychiatric diseases will play a significant role on our way to find proper causal therapies for these disorders.

\section{PATIENT HM - AN INDEX CASE TURNED INTO ENIGMA}

Henry Gustav Molaison (from literature known as “HM”) from Manchester, Connecticut was a patient with an intractable epilepsy attributed to a bicycle accident at the age of 7 . He developed partial seizures, which after his $16^{\text {th }}$ birthday turned into severe tonic-clonic epilepsy for which he underwent a surgery at the age of 27. William Beecher Scoville, the physician at Hartford hospital who performed surgery on HM's medial temporal lobes claimed and consequently reported that he has excised most of the complete hippocampal formation and adjacent structures, including most of the amygdala and entorhinal cortex (53). HM's seizure subsided, but he subsequently developed severe anterograde amnesia: he could not commit new events to explicit memory. He also had retrograde amnesia, but to a lesser extent and limited to memories not older than 11 years. Interestingly, his ability to form procedural memories was intact: he could learn new motor skills, despite not being able to remember learning them (53). The rest is history of science. Based on this single revelatory case, studies in animal models were prompted to show that the hippocampus plays crucial role in the consolidation of information from short-term to long-term memory (54). Interestingly, further examination of HM's brain done by magnetic resonance imaging (MRI) have hinted that the damage inflicted by surgery to the hippocampus proper was not so severe, whereas the complete entorhinal cortex, subiculum and amygdala were absent (55). Further, after his death (aged 82), HM's brain was serially cut and histologically analyzed, and the authors have confirmed the existence of an almost intact parts of the posterior hippocampus, including DG and CA4 fields (56). Furthermore, Annese et al. (2014) describe the previously unreported damage to the left prefrontal cortex, which could have further implications in HM's memory loss, as this structure has also been considered important for working memory formation in primates and in rodent species it is too small to be properly investigated (as reviewed in Goldman-Rakic, 1996). This brief overview of the HM case offers several insights into human brain research. Firstly, very often discoveries are made due to the 
"nature's experiment" - i.e. an unusual accident or disease course in a single patient, which lead to further experiments in animal models, establishing facts about brain function. Second, the true nature of the infliction to human brain can be reviled only posthumously and this, definitive diagnosis is essential to fully understand its impact on behavior.

\section{OUTLOOK}

As novel methods of brain imaging, particularly functional imaging emerge, one could falsely assume that oldfashioned morphological analysis of the human brain will be rendered obsolete. This article has tried to demonstrate that there are still many opened questions which are possible to resolve only through diligent analysis of human brain samples at histological and immunohistological level. Among those questions are the gender differences, left-right hemisphere differences, chromosome anomalies (most common being trisomy 21), development of unique structures, expression of adhesion molecules and ion channels. It is fair to say that we have just scratched the surface of possibilities that morphological research of the human brain opens. Therefore, we consider the development of new imaging techniques as complementary, and not substitute for histological research on human brain tissue. At all times, we must consider one of the main questions which drive neuroscience research. The import question, which defines our true nature - if this is our main anatomical difference from animals, then the answer to our uniqueness lies there. If brain is not the only difference, where lies the difference then?

\section{ACKNOWLEDGEMENTS} work.

We are grateful to Prof. Nada Zecevic for inspiring this

\section{LITERATURE}

1. DeFelipe J. Neuroanatomy and global neuroscience. Neuron 2017;95(1): 14-18.

2. Williams MF. Primate encephalization and intelligence. Med Hypotheses 2002;58(4): 284-90.

3. Pontarotti, Pierre (2016) Evolutionary Biology: Convergent Evolution, Evolution of Complex Traits. Springer. p. 74.

4. Juric-Sekhar G, Hevner RF. Malformations of cerebral cortex development: molecules and mechanisms. Annu Rev Pathol 2019;14: 293-318.

5. Jones EG. Neuroanatomy: Cajal and after Cajal. Brain Res Brain Res Rev 2007;55: 248.

6. Defelipe J. The evolution of the brain, the human nature of cortical circuits, and intellectual creativity Front Neuroanat 2011;5: 29.

7. Ferreira FR, Nogueira MI, Defelipe J. The influence of James and Darwin on Cajal and his research into the neuron theory and evolution of the nervous system. Front Neuroanat 2014;8: 1.
8. Jones EG. The origins of cortical interneurons: mouse versus monkey and human. Cereb Cortex 2009;19(9): 1953-6.

9. Duque A, Krsnik Z, Kostović I, Rakic P. Secondary expansion of the transient subplate zone in the developing cerebrum of human and nonhuman primates. Proc Natl Acad Sci U S A 2016;113(35): 9892-7.

10. Rash BG, Duque A, Morozov YM, Arellano JI, Micali N, Rakic P. Gliogenesis in the outer subventricular zone promotes enlargement and gyrification of the primate cerebrum. Proc Natl Acad Sci U S A 2019;116(14): 7089-94.

11. Radonjić NV, Ayoub AE, Memi F, Yu X, Maroof A, Jakovcevski I, Anderson SA, Rakic P, Zecevic N. Diversity of cortical interneurons in primates: the role of the dorsal proliferative niche. Cell Rep 2014a;9(6):21392151.

12. Saper CB. An open letter to our readers on the use of antibodies. J Comp Neurol 2005;493: 477-8.

13. Jakovcevski I, Zecevic N. Olig transcription factors are expressed in oligodendrocyte and neuronal cells in human fetal CNS. J Neurosci 2005;25(44): 10064-73.

14. Jakovcevski I, Filipovic R, Mo Z, Rakic S, Zecevic N. Oligodendrocyte development and the onset of myelination in the human fetal brain. Front Neuroanat 2009;3:5.

15. Ortega JA, Memi F, Radonjic N, Filipovic R, Bagasrawala I, Zecevic N, Jakovcevski I. The subventricular zone: a key player in human neocortical development. Neuroscientist 2018;24(2): 156-70.

16. Letinic K, Zoncu R, Rakic P. Origin of GABAergic neurons in the human neocortex. Nature 2002;417(6889): 645-9.

17. Kohwi M, Petryniak MA, Long JE, Ekker M, Obata K, Yanagawa Y, Rubenstein JL, Alvarez-Buylla A. A subpopulation of olfactory bulb GABAergic interneurons is derived from Emx1- and Dlx5/6-expressing progenitors. J Neurosci 2007;27: 6878-91.

18. Inta $\mathrm{D}$, Alfonso J, von Engelhardt J, Kreuzberg MM, Meyer AH, van Hooft JA, Monyer H. Neurogenesis and widespread forebrain migration of distinct GABAergic neurons from the postnatal subventricular zone. Proc Natl Acad Sci U S A 2008;105: 20994-9.

19. Haeckel, E. (1866) Generelle morphologie der organismen, vol 1, 2. Verlag Georg Reimer, Berlin.

20. Sousa AMM, Zhu Y, Raghanti MA, et al. Molecular and cellular reorganization of neural circuits in the human lineage. Science 2017;358(6366): 1027-32.

21. Fazzari P, Mortimer N, Yabut O, Vogt D, Pla R. Cortical distribution of GABAergic interneurons is determined by migration time and brain size. Development 2020;dev.185033. doi:10.1242/dev.185033

22. Anderson S, Mione M, Yun K, Rubenstein JL. Differential origins of neocortical projection and local circuit neurons: role of Dlx genes in neocortical interneuronogenesis. Cereb Cortex 1999;9(6): 646-54.

23. Rakic S, Zecevic N. Emerging complexity of layer I in human cerebral cortex. Cereb Cortex 2003;13(10): 1072-83. 
24. Marín O, Yaron A, Bagri A, Tessier-Lavigne M, Rubenstein JL. Sorting of striatal and cortical interneurons regulated by semaphorin-neuropilin interactions. Science 2001;293(5531): 872-5.

25. Jakovcevski I, Mayer N, Zecevic N. Multiple origins of human neocortical interneurons are supported by distinct expression of transcription factors. Cereb Cortex 2011;21(8): 1771-82.

26. Zecevic N, Hu F, Jakovcevski I. Interneurons in the developing human neocortex. Dev Neurobiol 2011;71(1): 18-33.

27. Hansen, DV, Lui, JH, Flandin, P, Yoshikawa, K, Rubenstein, JL, Alvarez-Buylla, A, et al. Non-epithelial stem cells and cortical interneuron production in the human ganglionic eminences. Nat Neurosci 2013;16: 1576-87.

28. Ma, T, Wang, C, Wang, L, Zhou, X, Tian, M, Zhang, Q et al. Subcortical origins of human and monkey neocortical interneurons. Nat Neurosci 2013;16: 1588-97.

29. Arshad, A, Vose, LR, Vinukonda, G, Hu, F, Yoshikawa, $\mathrm{K}$, Csiszar, A et al. Extended production of cortical interneurons into the third trimester of human gestation. Cereb Cortex 2016;26: 2242-56.

30. Raju CS, Spatazza J, Stanco A, et al. Secretagogin is Expressed by Developing Neocortical GABAergic Neurons in Humans but not Mice and Increases Neurite Arbor Size and Complexity. Cereb Cortex 2018;28(6): 1946-58.

31. Molnár Z, Clowry GJ, Šestan N, et al. New insights into the development of the human cerebral cortex. J Anat 2019;235(3): 432-51.

32. Altman J, Das GD. Autoradiographic and histological evidence of postnatal hippocampal neurogenesis in rats. J Comp Neurol 1965;124(3): 319-35.

33. Gross CG. Neurogenesis in the adult brain: death of a dogma. Nat Rev Neurosci 2000;1: 67-73.

34. Sorrells S, Paredes M, Cebrian-Silla A. et al. Human hippocampal neurogenesis drops sharply in children to undetectable levels in adults. Nature 2018;555: 377-81.

35. Boldrini M, Fulmore CA, Tartt AN, et al. Human hippocampal neurogenesis persists throughout aging. Cell Stem Cell 2018;22(4): 589-99.e5.

36. Kempermann G, Gage FH, Aigner L, et al. Human adult neurogenesis: evidence and remaining questions. Cell Stem Cell 2018;23(1): 25-30.

37. Boldog E, Bakken TE, Hodge RD, et al. Transcriptomic and morphophysiological evidence for a specialized human cortical GABAergic cell type. Nat Neurosci 2018;21(9): 1185-95.

38. Gabbott PL, Jays PR, Bacon SJ. Calretinin neurons in human medial prefrontal cortex (areas 24a,b,c, 32', and 25). J Comp Neurol.1997;381(4): 389-410.

39. Radonjić NV, Ortega JA, Memi F, Dionne K, Jakovcevski I, Zecevic N. The complexity of the calretinin-expressing progenitors in the human cerebral cortex. Front Neuroanat 2014b;8: 82.

40. Reinchisi G, Ijichi K, Glidden N, Jakovcevski I, Zecevic N. COUP-TFII expressing interneurons in human fetal forebrain. Cereb Cortex 2012;22(12): 2820-30.
41. Stanković-Vulović M, Zivanović-Macuzić I, Sazdanović P, Jeremić D, Tosevski J. [Morphology of neurons of human subiculum proper]. Med Pregl 2010;63(5-6): 356-60.

42. Vulovic M, Zivanovic-Macuzic I, Jeremic D, Stojadinovic D, Tanaskovic I, Popovic-Deusic S, Peljto A, Tosevski J. Morphometric characteristics of the neurons of the human subiculum proper. Archives of Biological Sciences 2012;64(3): 1157-63.

43. Radonjić NV, Jakovcevski I, Bumbaširević V, Petronijević ND. Perinatal phencyclidine administration decreases the density of cortical interneurons and increases the expression of neuregulin-1. Psychopharmacology (Berl) 2013;227(4): 673-83.

44. Schmalbach B, Lepsveridze E, Djogo N, Papashvili G, Kuang F, Leshchyns'ka I, Sytnyk V, Nikonenko AG, Dityatev A, Jakovcevski I, Schachner M. Age-dependent loss of parvalbumin-expressing hippocampal interneurons in mice deficient in CHL1, a mental retardation and schizophrenia susceptibility gene. J Neurochem 2015;135(4): 830-44.

45. Koszła O, Targowska-Duda KM, Kędzierska E, Kaczor AA. In vitro and in vivo models for the investigation of potential drugs against schizophrenia. Biomolecules 2020;10(1): 160 .

46. Cui YF, Hargus G, Xu JC, et al. Embryonic stem cellderived L1 overexpressing neural aggregates enhance recovery in Parkinsonian mice. Brain 2010;133(Pt 1): 189-204.

47. Djogo N, Jakovcevski I, Müller C, et al. Adhesion molecule L1 binds to amyloid beta and reduces Alzheimer's disease pathology in mice. Neurobiol Dis 2013;56: 10415.

48. Hargus G, Bernreuther C, Dihné M, Johann V, et al. Neural cell adhesion molecule L1-transfected embryonic stem cells promote functional recovery after excitotoxic lesion of the mouse striatum. J Neurosci 2006;26(45): 11532-9.

49. Momčilović M, Stamenković V, Jovanović M, Andjus PR, Jakovčevski I, Schachner M, Miljković Đ. Tenascin$\mathrm{C}$ deficiency protects mice from experimental autoimmune encephalomyelitis. J Neuroimmunol 2017;302: 16.

50. Filipovic R, Jakovcevski I, Zecevic N. GRO-alpha and CXCR2 in the human fetal brain and multiple sclerosis lesions. Dev Neurosci 2003;25(2-4): 279-90.

51. Alzheimer A, Stelzmann RA, Schnitzlein HN, Murtagh FR. An English translation of Alzheimer's 1907 paper, "Uber eine eigenartige Erkankung der Hirnrinde". Clin Anat 1995;8(6): 429-31.

52. Lewy FH. Zur pathologischen Anatomie der Paralysis agitans. Dtsch Ztschr Nervenheilkunde 1914;50: 50-5.

53. Scoville WB, Milner B. Loss of recent memory after bilateral hippocampal lesions. J Neurol Neurosurg Psychiatry 1957;20(1): 11-21.

54. Anderson, P., Morris, R., Amaral, D., Bliss, T. \& I'Keefe. (2007) The hippocampus book (first ed.). New York: Oxford University Press. 
55. Corkin S, Amaral DG, González RG, Johnson KA, Hyman BT. H. M.'s medial temporal lobe lesion: findings from magnetic resonance imaging. J Neurosci 1997;17(10): 3964-79.

56. Annese J, Schenker-Ahmed NM, Bartsch H, Maechler P, Sheh C, Thomas N, Kayano J, Ghatan A, Bresler N, Frosch MP, Klaming R, Corkin S. Postmortem examination of patient H.M.'s brain based on histological sectioning and digital 3D reconstruction. Nat Commun 2014;5: 3122 . 